\title{
PUBLIC AUTHORITIES IN THE UNITED STATES
}

\author{
ROBERT GERWIG*
}

\section{Foreword}

The terms "Authority" and "Public Authority" have become bywords in legislative planning for long-range development of State institutional facilities.

From an extensive 1956 study by a New York legislative commission, called upon to investigate multi-billion dollar Authority operations in that State, came this declaration: ${ }^{2}$

The public authority is one of the most significant of developments in modern governmental administration. It has captured the imagination of the public and has gained substantial support in the investing community. Over the last fifty years the public authority device has grown into a significant element of government. ... So great has been its growth that the public authority requires recognition as a significant vehicle for public administration.

An earlier survey by the Council of State Governments, made at the request of the Governors Conference of 1952, found that since World War II the States increasingly have adopted legislation setting up Public Authorities to finance and construct a variety of governmental services. ${ }^{3}$

To avoid becoming enmeshed in a complicated governmental proliferation which is roughly bounded on one side by purely political subdivisions and by whollyowned government or public corporations ${ }^{4}$ on the other, it is necessary to adopt a working description of a standard Public Authority. Therefore, in broad terms for the moment, a Public Authority will be deemed to be a limited legislative agency or instrumentality ${ }^{5}$ of corporate form intended to accomplish specific purposes involving long-range financing of certain public facilities without legally or directly impinging upon the credit of the State.

- LL.B. 1948, Atlanta Law School. Attorney, Atlanta, Ga. Member of Federal, Georgia, and Atlantá Bar Associations. Contributor to legal periodicals.

${ }^{1}$ For an earlier treatment of the subject by the author, see Gerwig, Public Authorities: Legislative Panacea?, 5 J. Pus. L. 387 (1956).

${ }^{2}$ New York Temporary State Comm'n on the Coordination of State activities, Public Authorities Under New York State 3 (1956) [hereinafter cited as N.Y. Study].

* ${ }^{3}$ Councr of State Governments, Public Authorities in the States I (r953) [hereinafter cited as Council Reporti].

The standard description of public corporations evolves from an opinion by Justice Story in a famous case: ". . . public corporations are such only as are founded by the government for public purposes, where the whole interests belong also to the government." Trustees of Dartmouth College v. Woodward, 17 U.S. (4 Wheat.) 518, 668-69 (1819). Public Authorities thus are a type of the broad form of public corporation but have distinguishing characteristics, as will be seen.

'The agency or instrumentality here contemplates the entity created by the State for the accomplishment of a particular State function, and not the means through which the State as a sovereign effectuates its governmental functions. The intended result of this process, inter alia, is to make the Public Authority responsible for its independent actions, apart from liability, if any, of the State. 


\section{The Semantic Problem}

The Public Authority mechanism has undergone so many mutations that the fundamental kinship is sometimes difficult to recognize. In fact, the true nature of the Public Authority often is so camouflaged that discouragement frequently faces the questioner when seeking basic information on the subject.

We begin our quest with the lexicographers: Webster, after giving the primary meaning of the word "authority" as legal or rightful power, tells us in a secondary definition that "authority" can be a person or a board or commission having quasigovernmental power in a particular field, as a Port Authority; and his legal cousin Black would have us understand, by the definition most pertinent to this commentary, that in the English law relating to public administration, an Authority is a body having jurisdiction in certain matters of a public nature.

Added to the difficulty of a common precise understanding of the term "Authority" as used for our purposes is a lack of uniformity in classification or indexing of data pertaining thereto. ${ }^{6}$ Because of near limitless variations of the Authority form in practice, related treatises and source materials confront the researcher with a dismaying array of overlapping and duplicitous signposts. To arrive at a reasonably predictable destination the Authority traveler must, in the probable absence of direct signals like "Public Authorities," follow tortuous detours into generalities found under such headings as States, State Governments, State and Local Governments, State Corporations, Public Administration, Public Finance, Public Corporations, Revenue Bonds, etc. Of course, the more seasoned voyager most likely will head for a specific terminal point, as the [State] Port Authority, and then make similar calls to a specific State Building or Toll Bridge Authority, etc.?

To heighten the spirit of the chase, legislators with seeming abandon occasionally discard the word "Authority" altogether in favor of "commission," "board," or "corporation." Current fashions tend toward even more generalized combined forms like State public benefit corporations, ${ }^{8}$ or municipal supplementary public corporations and special purpose public bodies. ${ }^{9}$ And those who would track the Authority of pioneer days must be cognizant of trading companies, water and other special district or area designations. No more than passing note can be given to myriad Authorities spawned by political divisions subordinate to State legislaturesmunicipal, county, and other intrastate development bodies. Beyond these still are

\footnotetext{
"To avoid complications with the generic term "authority," the capitalized forms, Authority or Public Authority, will be used when referring to public entities, as distinguished from an abstract term signifying power.

"Although standard indexes of source material have begun to accumulate pertinent entries under the heading "Authorities," a lead to a specific Authority is still a good bet.

${ }^{8}$ N.Y. STUDY $63-67$.

- 3 Chester James antieat, Municipal Corporations Law ch. 28 (ig60); Charles S. Rhyne, Municipal Law 6-7 (1957).
} 
the "outer-space" counterparts-interstate and regional Authorities which transcend normal political boundaries even as astronauts pass through traditional Earth-bound courses.

Specific use of the term "Authority" does not necessarily admit a unit, not otherwise qualified, into the close society of standard Authorities. Thus, even the giant: Tennessee Valley Authority-though a valuable model of techniques and administration-does not qualify as a bona fide Authority within the sense of this discussion: because of its lack of financial autonomy. ${ }^{\mathbf{1 0}}$ Examples of other types which generally will not be included here except perhaps for passing reference are those development: and credit Authorities which are substantially dependent upon the parent body for financial support and those which, despite the Authority label, are simply State administrative agencies or "atypical" Authorities, as one editor has distinguishedi some of the extreme offshoots. ${ }^{11}$ As the newer Authorities are established with less; autonomy, it may become desirable and even necessary to distinguish "independent" Authorities from those which are subject to close control.

Some current text writers on governmental operations have recognized the growth of the Authority instrumentality to the extent of including a subchapter on one or more phases of the topic. ${ }^{\mathbf{1 2}}$ Others refer at least hurriedly to new types of public financing with a reference to the archetype of American Authorities-the Port of New York Authority. ${ }^{13}$ Occasionally, even among the late texts, there will be but a single sentence noting the emergence of separate Authorities "or corporations" which borrow or spend for the State without technically using the State's. credit. $^{14}$

However, sometimes an author will devote an informative and analytic chapter on what at least in some areas are described as established agencies of local government, including Authorities. ${ }^{15}$ An advance in the maturity of Authorities as a. distinct unit of public activity was the inclusion in a standard casebook of a brief: analysis of local government problems affecting Authorities. ${ }^{16}$

Major milestones in the recognition of Authorities are reflected by the studies: conducted by the Council of State Governments and the New York LegislativeCommission $^{17}$ and finally at least partial consideration by the 1957 Census of:

${ }^{10}$ E.g., Austin J. Tobin, Executive Director, Port of New York Authority, from an address at Rutgers. University, March 26, x953, p. II n.9; comment by Mr. Raymond Moley, quoted by Mr. Tobin, supra, p. 15; Ford P. Halz, Government and Business 548 (1949); Morris, Euading Debt Limitations with. Public Building Authorities: The Costly Subversion of State Constitutions, 68 YAL.E L.J. 234, 235 n.2. (1958).

${ }_{11} 3$ ENCrc. GA. LAw, Authority Financing $\$ 6$ (196r).

13 E.g., Albert B. Sayre, Georgia Government and History 334-37 (I957).

${ }^{13}$ For a more detailed discussion of the Port of New York Authority, sce Goldstein, An Authority inz Action-An Account of the Port of New York Authority and Its Recent Activities, infra, at 715-24.

${ }^{14}$ E.g., William Anderson, Clara Penniman \& Edward W. Weidner, Government in trete Fifty! StATES 339-40 (1960).

${ }^{15}$ To be found only after piercing the veil of the title: John C. Bollens, Speciar. DisTrict GovernMrents in the United States ch. 7, Dependent Districts and Authorities (1957).

10 Jefferson B. Fordians, Locar Governament Law 33-34 (I949).

${ }^{17}$ See notes 2, 3 supra. 
Governments, ${ }^{18}$ all of which spotlighted what had theretotore been little more than an experiment in public finance. ${ }^{19}$

At least one encyclopedia of local law in a State which has been in the forefront of the recent Authority movement soon will contain a full analysis of local Authorities in general with a supplemental chapter on local housing Authorities. ${ }^{20}$

Thus, while the study guides are not yet so well marked as to provide unmistakable paths of research, nevertheless Authorities have attained status to the point where a relatively substantial body of source material has become available to the diligent searcher, who should be able to identify and classify a given Public Authority as an amalgam of various types of corporate or administrative structure established by legislative enactment to finance (primarily by means of revenue anticipation bonds), construct, and maintain a public facility, the user-charges for which will be expected to defray the necessary debt service.

Perhaps the best description of the true Authority is that offered by an experienced Authority administrator: ${ }^{21}$

... a public corporation set up outside the regular framework of federal, state or local government, and freed from the procedures and restrictions of routine government operations, in order that it may bring the best techniques of private management to the operation of a self-supporting or revenue-producing public enterprise.

II

Historical Development

Ambiguity concerning Authorities is not restricted to problems of definition and recognition. Difficulties encountered in charting the early history of Authorities are traceable to similar confusion arising from the many-sided nature and purposes of what has evolved as a singular legislative device for coping with fiscal problems confronting large-scale development in public activity areas.

Because the Authority essentially is of corporate structure (modified, to be sure, by whatever "quasi" form appears appropriate), perhaps it is not surprising to find that the genesis of Authorities can be discovered in the interesting history surrounding the origin of corporations. In at least one discourse on the embryonic manifestation of the corporate birth, the fact of propinquity (as within the ancient concepts of family, clan, and tribe) in itself was used as the basis for combining identity of interest to achieve a common purpose. Thus, it was concluded, the corporation "grew by nature," but for political expediency it became necessary to "create" corporations by sovereign power. ${ }^{22}$ Similarly for fundamental reasons of revenue and control, early English communities of interest (e.g., boroughs and guilds) were subjected to forms of incorporation primarily for public purposes

${ }^{18}$ I U.S. Bureau of the Census, Dep't of Commerce, i957 Census of Governments, No. 3, Locat Govérnment Structure (1958).

${ }^{10}$ With the exception of the massive Port of New York Authority. See Goldstein, An Authority in Action-An Account of the Port of Neav York Authority and lts Recent Activities, infra, at 715-24.

${ }_{30}{ }_{3}$ EnCyc. GA. LAw, Authority Financing $\$ \$ \mathrm{I}-45$ (1961); id. Housing Authorities (to be published).

21 Tobin, supra note I0, at 15 .

${ }_{22}$ Raymond, The Genesis of the Corporation, I9 HARv. L. Rev. 350, 362 (xgo6). 
before the general development of the private corporation. An experienced observer of business and governmental affairs recently underscored the public nature of such developments by describing the early English corporations as evidence of an "extended arm of royal power to get things done." ${ }^{\text {"3 }}$ Another area of medieval Authority activity can be illustrated by reference to the early city-states of Genoa and Venice, which developed Public Authorities to administer maritime law and control port traffic. ${ }^{24}$

From the original premise of a corporation as a governmental technique, it is but a relatively simple matter to telescope the centuries of time during which the corporate form was refined. A brief halt at a way station, however, would focus attention momentarily upon the earliest use of corporations in the then New World to exercise basic functions of public government by way of English colonial charters. In fact, it even has been suggested that the basic form of public government in America derived from a so-called commercial-or rather, proprietary-corporation: the Virginia Corporation, which was chartered in $1606 .{ }^{25}$ The historic trading companies of the early seventeenth century, organized to promote commerce between North America and Europe, indeed have been cited as forerunners of today's Public Authorities. ${ }^{26}$

Except for purposes of remote historical ancestry, the Public Authority of today's generally accepted form may be traced back to the early nineteenth century patterns of American public finance. The first great wave of over-optimistic speculation, coupled with reckless expenditures related to State-sponsored activities, such as railroads, turnpikes, canals, banks, etc., came to a halt with the depression of the late 1830 's. Many of these enterprises were doomed from the outset because of their sponsors' combined lack of business administrative techniques and appreciation of business methods and judgment. ${ }^{27}$ Irresponsible financial administration by State legislatures and their agencies resulted in widespread default of State-guaranteed debts. Inevitable reactions of public resentment and humility led, in turn, to general enactment of severe constitutional restrictions upon the power of legislatures and the use of State credit. $^{28}$ By 1857 , more than half of the States had amended their constitutions to restrict borrowing powers and, following the fiscal turbulence of the Civil War and Reconstruction periods, most of the remaining States, including those newly admitted, enacted some type of constitutional debt

${ }^{23}$ Adolf A. Berle, Jr., Foreword to The Conporation in Modern Societr (Mason ed. 1960). See also Jewell Cass Philitis, State and Local Governaent in America ch. 15 (I954), tracing the preAnglo-Saxon beginning and Anglo-Saxon pattern's of local government. For a recent survey of the companion rules of State and corporation, see Harbrecht \& McCallin, The Corporation and the State in Anglo-American Law and Politics, ro J. Pub. L. 47 (I96r).

" Marvin L. Fair, Port Administration in the United States 14 (I953).

${ }^{25}$ Latham, The Body Politic of the Corporation, in Edward S. Mason (ED.), The CoRporation IN MOdern Society ch. II (I960).

${ }^{20}$ Council Report 21.

${ }^{27}$ Harold Koontz \& Richard Gable, Public Control of Economic Enterprise 698 (1956).

${ }^{28}$ Council Report 9, II; Almond v. Day, I97 Va. 782, 9I S.E.2d 660 (1956); and Annot., I52 A.L.R. 495 (1944). 
srestriction. Generally, such restrictions limited gross amounts of borrowing, placed a ceiling on borrowing by reference to a percentage of the assessed valuation, or restricted borrowing to total tax revenues. Many provided for the additional requisite of popular referendum. ${ }^{29}$

Interwoven in the debt pattern were the development of revenue bond financingiby which the borrowing agency could finance public enterprises out of revenue from .charges paid by users of the facilities-and the emerging dominance in the public mind of the corporate form of organization as a symbol of effective business administration in an urban industrial society. ${ }^{30}$

But widescale adaptation of the corporation to the function of public enterprise as a means of solving constitutional debt limitations did not come at once. True, there were some experimental gestures of public borrowing through revenue bonds paid only from the income of revenue-producing enterprises, but these were linked mostly with the improvement of water systems. ${ }^{31}$ The Authority was still untested in a large sense, although it was experiencing "growing pains."

A giant step in the development of Public Authorities came in $x$ gi with the .establishment of the Port of New York Authority-patterned in part after the Port of London Authority, created twelve years earlier-which was to become the archetype of Public Authority administration in this country.

The massive development, scope, and accomplishments of the Port of New York Authority are explored in another portion of this Symposium. ${ }^{32}$ We shall linger only long enough to note that the Authority represented a major compromise between two States to reconcile longstanding and complicated jurisdictional problems of a sprawling and congested terminal area. It should be observed also that the establishment of the interstate agency reflected at the time a rare use of the compact clause of the Federal Constitution. ${ }^{33}$ Perhaps mention should be made of the fact that the Port Authority's successful operation fathered a by-product in the Authority pattern-use of the income of paid-up facilities to finance additional facilities not within the original contemplation of the initial bond issues, thus tending to perpetuate the Authority's existence.

Additional Authorities appeared in the United States at a relatively slow rate for the next several years. ${ }^{34}$ Some States enacted revenue bond legislation authorizing regular units and agencies of government to employ such method of financing. ${ }^{35}$ 'The depression of the early I930's brought on a drastic reduction in State financial programs and contributed to the rise of Authority-financing as a means of supporting

${ }^{20}$ For a summary of constitutional restrictions, see Council Report II-r8.

${ }^{30}$ Council Report ch. 2.

${ }^{31}$ E.g., special water districts in Maine at the turn of the twentieth century.

${ }^{39}$ See Goldstein, An Authority in Action-An Account of the Port of New York Authority and Its Recent Activities, infra, at 7I5-24.

83 'No State shall, without the Consent of Congress . . . enter into any Agreement or Compact with another State . . . U.S. Const., art. I, $\$$ ro. See joint resolutions of Congress granting consent, 42 Stat. $\mathrm{I}_{74}, 822$ (I921). Although the compact clause had been used frequently in interstate relations, it had not theretofore been used as the basis for a permanent interstate body.

${ }^{34}$ Council REPORT 25.

${ }^{85}$ Ibid. 
public works. A prime stimulus was given the Public Authority technique in 1934 when President Roosevelt addressed a letter to the governors recommending legislation that would enable greater participation in Federal public works. The President indicated the feasibility of State legislation authorizing the issuance of revenue bonds to finance revenue-producing improvements and suggested that such authority be given not only to existing governmental agencies but also to newly created public corporations. ${ }^{36}$ The legal division of the Public Works Administration was placed at the disposal of the States, and much of the stimulation as well as the form of Authority legislation may be credited to its staff. ${ }^{37}$ The reaction to what seemed a custom-made remedy for State fiscal ills was immediate: at least nineteen States established Authorities for financing revenue-producing projects within two years, and by I95I forty-one States had enacted legislation to establish Authorities. ${ }^{38}$

Enthusiastic resort to Authorities provoked concern in some quarters, lest too hasty adoption of a magic formula might lead to disappointment. Thus in $1936 \mathrm{New}$ York's Governor Lehman, responding to demands for increased Authority financing in that State, warned that although the Authority might well be a reasonable method to reach a desired end, nevertheless such an agency should not be created to displace permanent and regular government agencies; and he urged the New York legislators "to exercise great restraint and care" in establishing additional Authorities."

The advent of World War II interrupted State programs for constructing public improvements. The resulting backlog of needs in the usual areas of State responsibility for transportation (including port and terminal facilities, highways, bridges, tunnels, ferries, and transit systems) was soon multiplied many times by unprecedented post-war needs for housing and public buildings (including schools and dormitories, administrative offices, courts, etc.), dams, airports, hospitals, armories, and parking facilities. The ever-widening purpose of Authorities has been extended to recreational facilities, garbage disposal plants, and steam heating and distribution systems. Somewhat far removed from the ordinary ambit of Authorities, one can find such objectives as industrial exhibits, municipal theaters, planetariums, war memorials, and mineral springs. The practice of utilizing Authorities for other than standard government functions suited to revenue bond financing has been questioned. ${ }^{40}$

By 1955, New York alone legislatively created fifty-three Authorities, of which thirty-three were then still active, ${ }^{41}$ with assets of $\$ 2.3$ billions, liabilities of $\$ 1.8$ billions. These figures included Authorities on all recognized levels, municipal, county, regional, and State.

A recent survey in Pennsylvania listed Ir4̧o municipal Authorities, reflecting

${ }^{30} \mathrm{Id}$. at 26.

${ }^{87}$ Foley, Revenue Financing of Public Enterprise, 35 Mich. L. Rev. I (x936).

${ }^{3 s}$ Council Report 27.

so Tobin, stupra note Io, at $\mathrm{II}$.

10 Ibid.

"Some were abolished, having accomplished the purpose for which formed; others were consolidated, and at least one remained inactive. N.Y. STUDY 583-85. 
issuance of almost \$ billion worth of bonds, mostly for purposes of schools, waterworks, and housing. This spectacular growth followed a liberal $x 945$ statute which has been described as "the broadest Authority legislation in the nation."

In the Sixth Federal Reserve District, the full-faith-and-credit debt of six Southern States dropped from eighty per cent of total debt outstanding in 1946 to thirty-four per cent by 1957. The sharp rise in non-State-guaranteed debt was attributed to the remarkable growth of revenue bond-issuing Authorities. In 1957, thirty-two of such agencies reported outstanding bonds of close to \$r billion, primarily for roads, bridges, and schools..$^{43}$

Nationally, Department of Commerce data showed $\$ 16.9$ billion of State debts outstanding at the end of fiscal 1959. Almost half of this figure represented nonState-guaranteed debt of $\$ 8.2$ billion, ${ }^{44}$ most of which is believed attributable to Authority-type financing.

More recently, significant Authority developments have tended to break away from the so-called basic type concerned with construction and operation of specific facilities financed solely by the issuance of revenue bonds to be amortized from earnings of the projects. Prominent among the newer types are Area Development Authorities devoted primarily to the expansion of industry and commerce in metropolitan areas. ${ }^{45}$ They also may be known as Industrial Credit Authorities, and usually are empowered to make mortgage loans to non-profit corporations in critical economic areas. The principal purpose of these federally-supported State lending agencies is the promotion of industrial development, and their funds are used for industrial construction in manufacturing industries. Much of the stimulus for their current popularity results from direct financial support through the resources of the Small Business Administration. ${ }^{40}$ The variety of the statutes and of the organizations created thereunder have been described as a demonstration of the effectiveness of our federal system, under which the several States can experiment and devise special forms to serve particular needs and conditions, benefiting from the experience of others. ${ }^{47}$ Other offshoots which can trace kinship to the Authority are

${ }^{2}$ Pennsylvania's Billion Dollar Babies, Federal Reserve Bank of Philadelphia reprint from Bus. Rev., March 1958, pp. $x, 4$. A modest footnote to one of the charts therein indicates that 70 more muncipal Authorities were authorized in 19571

${ }^{4}$ Spending for Public Improvements, Federal Reserve Bank of Atlanta, Monthly Review of Business Conditions in the Sixth Federal Reserve District, October x958, pp. I, 3. The area includes Alabama, Florida, Georgia, Louisiana, Mississippi, and Tennessee.

"U.S. Bureat of the Census, Dep't of Commerce, Summary of State Government finances in I959, at 4 (1960).

${ }^{15}$ See, e.g., Netherton, Area-Development Authorities: A New Form of Government by Proclamation, 8 VAND. L. REV. 678 (I955).

${ }^{16}$ Small Business Investment Act of 1958, 72 Stat. 697, I5 U.S.C. \$ 687. "Development companies" are defined therein as "enterprises incorporated under State law with the authority to promote and assist the growth and development of small-business concerns in the areas covered by their operations," 72 Stat. 690,15 U.S.C. $\$ 662$ (1958).

"Staff of Senate Comm. on Banking and Currency, 86th Cong., ist Sess., Development Copporations and Authorities, Reports, Statutes, and Other Materials on State and Local Development Corporations and Authorities vii (Comm. Print 1959). For recent judicial approval and citation of cases indicating similar approval in other States, see Industrial Dev. Authority v. Eastern Kentucky Regional Planning Comm'n; 332 S.W.2d 274 (Ky. Ct. App. 1960). 
commodity corporations and similar units intended to stimulate credit in specific trading areas.

Although as indicated, the latter combinations are not entirely of the financially autonomous variety-generally the traditional trademark of a standard Public Authority-they are nevertheless to be reckoned with as a direct result of the Authority pattern of growth. Just as the "normal" statistics disseminated by the Weather Bureau are determined in part by current happenings, yesterday's standard Authority may be something different tomorrow-because of today's developments.

Primary stress has here been placed upon State-created Authorities in order to project what has seemed to be a fair overview of the variables manifested by these instrumentalities. The Authority, of course, flowers equally well and perhaps more profusely in some areas under the aegis of the municipality or the county or related geographic region. Authorities under the latter auspices have not been considered in much detail because their practices involve largely the same general considerations as their State prototypes.

\section{III}

\section{The Anatomical Structure}

As the Public Authority finds its heritage in the origin and development of the corporation, it will be treated as a special corporation and its formation, powers, and organizational form considered in such light. Here again it should be noted that although many Authorities will be affected by the items herein considered, an "average" Authority probably is a fictional hypothesis, as each Authority is by nature tailor-made to accomplish specific purposes.

Certain questions have been suggested as a handy guide for consideration in determining whether the Public Authority (as distinguished from a department of State Government) is a suitable instrumentality for operating the enterprise:

Is the project self-supporting?

Does it require business efficiency?

Will primary decisions be of a business character?

Are such decisions beyond partisan political considerations?

Are initiative, imagination, and risk-taking required?

Is it important that there be continuity of policy?

Does the program involve an area beyond established political boundaries?

An Authority may be feasible even if all the questions cannot be answered affirmatively, but if most of the answers are negative the establishment of what in effect will be a new division of government probably would be highly questionable. ${ }^{48}$

Assuming that the necessary prerequisites for a given project have been considered and determined affirmatively, the Public Authority, for the purposes of this discussion, ordinarily evolves in the womb of the legislative process. It is intended to be a fiscal instrumentality of the State, generally autonomous in its administration,

18 Tobin, stipra note 10 , at $32,13$. 
charged with creating and maintaining a specific facility, such as a port, bridge, highway, transit system, or any of the myriad services demanded by a modern metropolitan complex.

Usually, the Public Authority is spawned by a special legislative enactment, but it may be the product of executive action under a general incorporation statute. ${ }^{40} \mathrm{~A}$ basic legislative scheme embodying special acts for the creation of individual Public Authorities but also containing general provisions applicable to all Authorities affords a logical approach to the dual problem of creating an organization to accomplish a specific goal and permitting standard treatment in the interpretation of limitations or powers common to all Authorities. Legislative power to create a corporate Authority has generally been held to be sufficiently broad to permit the utilization of the Authority device for practically any governmental function capable of being delegated..$^{50}$

Regardless of its title, ${ }^{51}$ the so-called standard Authority normally is recognizable as a corporation with at least the usual attributes possessed by large private business corporations. These generally will include the standard powers to execute contracts, to sue and to be sued, to purchase and hold land, to have a seal, to employ personnel, to make by-laws, to manage its own affairs, and to do all things necessary to accomplish stated powers. Powers indicating independent authority have been regarded as a prime requisite on the theory that if direct control should be maintained by the general government, the result would be a pure government instrumentality not manifesting the managerial independence necessary for the usual Authority-type operation. The less independent the Authority, the greater the impossibility of fulfilling its traditional objective of overcoming the barrier of constitutional limitations on public spending.

In the case of the Port of New York Authority, the governors of New York and New Jersey have equal veto rights, but this statutory power rarely has been invoked.52 The reverse side of the coin also should be noted: when an adverse court decision indicated that the Port of New York Authority was not authorized to accomplish an important addition to one of its facilities, both the New Jersey and New York legislatures quickly supplied the missing grant by legislative action. ${ }^{\text {b3 }}$

Clothed with standard corporate powers, the Public Authority normally derives financial support from the sale of revenue bonds. Therefore the corporate grant

$1{ }^{\circ}$ Council Report 38.

50 "A State has the right to exercise all its governmental functions and, in the interest of public welfare, various proprietary functions, but unless there is a constitutional requirement to be met, it is free to delegate either governmental or proprietary functions to either public or quasi public corporntions." Hope Natural Gas Co. v. West Virginia Turnpike Comm'n, I05 S.E.2d 630, 637-38 (W. Va. 1958). And see 8I C.J.S. States 5 ror (1953).

${ }^{51} \mathrm{Be}$ it remembered that the Authority operation may be masked by the label of "commission," "board," "project," and occasionally by "district," although the latter term rarely is applied in current legislation creating an Authority mechanism.

${ }^{52}$ COUNCII RePORT 6I, 62.

${ }^{88}$ Note, The Applicability of Sovereign Immunity to Independent Public Authorities, 74 Harv. L. REv. 714, 720 n.33 (I96I). 
specifically must empower the Authority to issue revenue anticipation bonds for the particular or general purpose of the project or projects for which the Authority was created. Ordinarily, statutory provisions expressly prohibit any pledging of the State's credit, although there are some exceptions to this rule. ${ }^{54}$

Incidental powers usually will include competence to fix and charge rates, rents, or tolls, and to accept grants. Important powers to exercise eminent domain, issue subpoenas, and to provide police protection and regulation, also may be included, but such powers are generally granted only if their exercise is required to enable the Authority to accomplish its goals.

Authorities usually are governed by a board of directors but may be organized with a single executive. As with private corporations, this is a key aspect which generally dominates the efficient Authority operation. Without superior, properly motivated board or executive personnel, the managerial independence of the Authority can assume the burden of an albatross. Most directors are not paid salaries but are usually given a per diem rate to cover expenses. If the chairman of the board performs substantial managerial functions he usually is paid a salary. Generally, however, especially in large Authority operations, members of the governing body perform policy functions, leaving the daily routines to salaried administrators.

The usual alternative to the selection of top caliber businessmen is resort to ex-officio appointment of public officers. Extensive use of State officials lessens the Authority's independence of action and enhances the State's desire to oversee the Authority. Surveys indicate that the governor, an important finance official (e.g., the treasurer, comptroller or auditor), and the attorney general are most apt to be named as ex-officio appointees. ${ }^{55}$ Some States provide for appointment of legislators, ${ }^{56}$ but this procedure has been condemned as unconstitutional in at least one instance as in violation of a constitutionally required division of powers. ${ }^{57}$

Except where provided otherwise by statute, appointment usually is by the governor, occasionally subject to legislative consent or nomination by private groups; and sometimes by election. ${ }^{58}$ Removals, ordinarily only for cause, are usually at the discretion of the governor. ${ }^{59}$ Overlapping terms of members appear to be favored..$^{60}$ Board officers usually serve in part-time capacity, with full-time managerial supervisors.

Authorities usually are exempt from routine budgetary review and centralized

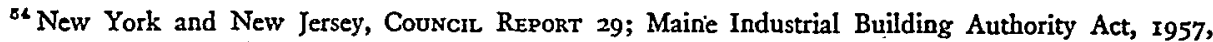
ME. Rev. Stat. ANn. ch. 38-B, $\$ 3$ (I959 Cum. Supp.), approved in advance in Opinion of the Justices, I53 Me. 202, 136 A.2d 528 (1957).

BS Inclusion of the attorney general and-though this is rare-supreme court justices as members would seem to impinge upon the performance of official legal duties pertaining to Authority operation or litigation.

${ }^{50}$ Council Report table at 44 .

${ }^{57}$ Book v. State Office Bldg. Comm'n, r49 N.E.2d 273 (Ind. 1958).

${ }^{8 B}$ Council Report 42.

${ }^{50}$ Id. at 45 .

${ }^{\circ}$ Id. at 47. 
personnel procedures, ${ }^{61}$ though the extent of control varies. Authority records may be subjected to an independent audit, with direct legislative control over disposition of revenues, in addition to the positive check of specific statutory debt limitations. Provision also may be made for submission of reports to the governor or legislature. ${ }^{02}$

The fiscal apparatus of the Authority has been likened to the heart of the creature, ${ }^{63}$ and this is indeed true, as will be seen from an examination of the detail of Authority financing. ${ }^{64}$ Upon retirement of the bonds issued to finance the undertaking, the Authority normally conveys the property to the State. The fiscal operations of an Authority may be successful enough to enable it not only to become selfsufficient as to its immediate objective-such as the liquidation of the cost of a port project-but also to finance other related projects out of subsequent surpluses from the initial operation, as has been true in the case of the Port of New York Authority. ${ }^{\text {or }}$

In the formulation of techniques and procedures for Authority operations, the States have produced varying solutions to the basic problem of combining managerial independence and public accountability. ${ }^{{ }^{63}}$ Thus, Authorities generally enjoy sufficient financial autonomy and freedom from administrative controls to permit operation in an atmosphere comparable to that of private enterprise. Still, the States have imposed certain -constitutional, statutory, and administrative limits upon the freedom of Authorities, in addition to specific supervisory controls, especially by gubernatorial appointment. Variations and degrees of autonomy and control can be determined only upon careful scrutiny of the particular Authority under examination, and general observations of this nature would be of little relevance and practical value.

\section{IV}

\section{Federai Census Constderations}

The problem of accurately identifying and classifying Authorities was encountered by the federal government in its effort to conduct a census of governmental units. ${ }^{67}$ In its 1957 census of governments, the Bureau of the Census outlined certain essential characteristics which a prospective unit must meet for inclusion as a governmental unit: ( $\mathrm{I}$ ) existence as an organized entity; (2) governmental character; and (3) substantial autonomy. ${ }^{68}$

\footnotetext{
${ }^{61}$ Most Authorities which are not under State personnel systems have not established their own merit systems, and in only a few instances are employees covered by special acts. Councrl Repont 60.

${ }^{62}$ See note 48 supra.

${ }^{68}$ Netherton, supra note 45 , at 686.

on See Jones, The Financing of $T V A$, infra, at 725-40.

${ }^{65}$ Netherton, supra note 45 , at $68 \mathrm{r}$.

${ }^{68}$ CoUnCIL Report 64.

${ }^{67} 7$ I Stat. 483 (1957), 13 U.S.C. $\$$ I61 (1958) provides: "The Secretary [of Commeree] shall take, compile and publish for the year 1957 and for every fifth year thereafter a census of governments. Each such census shall include, but shall not be limited to, data on taxes and tax valuations, governmental receipts, expenditures, indebtedness, and employees of States, counties, cities, and other governmental units."

${ }^{88}$ I U.S. Bureau of the Census, Dep't of Commerce, 1957 Census of Gevernments, No. 1, Governments in the UNIted States 9 (1958) [hereinafter cited as I957 Census].
} 
Many major Authorities in fact, but in varying degrees, substantially embody each of the stated essentials. However, the Bureau found that as a class, Authorities resemble special districts created to serve a single function or a limited number of functions; but that in many instances the functions were assigned in lieu of, or to supplement, services ordinarily provided by an established government, and that most Authorities were not sufficiently autonomous to be classed as governmental units. ${ }^{\text {B }}$

For example, in counting State and local governmental units, the Bureau considered listing statutory Authorities and other similar organizations having certain characteristics of "independent governments," but determined that administrative or financial control by the State or other local governments (i.e., counties, municipalities, townships and towns, school districts, and special districts) required classification of such units as "subordinate agencies" of such other governments rather than as independent units. ${ }^{70}$ The Bureau's conclusions also may have been prompted by assigning considerable weight to such factors as ex-officio appointments to the Authority governing body and certain other intangibles. ${ }^{71}$

Apparently, the Bureau was not completely satisfied with its selection standards, for in view of the "infinite variety of provisions regarding local government entities and particularly the shadings of autonomy which they exhibit," consideration also was given to "(I) local attitudes as to whether the type of unit involved is independent or not, and (2) the effect of the decision upon collection and presentation of statistics of government finances and employment.".72

However, many Authorities generally at the sub-regional, county, or municipal level were included among the 14,405 special districts listed in the Census. As a result, some Authorities are included in the census statistics, but many are not, ${ }^{73}$ so that no accurate count of the elusive Authorities appears to be available. ${ }^{74}$ Authorities as a whole seem to be regarded as officially existing in a sort of anonymous dependency status, attached, more or less, to the 102,328 governmental units which were enumerated by the Bureau. ${ }^{75}$

The importance of Public Authorities as a distinctive technique in modern governmental administration suggests that the Bureau of the Census might well consider

\footnotetext{
${ }^{00}$ Id. at 7. Many special districts possess limited taxing powers and may be directly responsible to the electorate-characteristics not normally attributable to Public Authorities.

${ }^{70} \mathrm{Id}$. at 12.

${ }^{71}$ I 1957 Census, No. 3, Local Government StructuUte 3-4.

${ }^{72} \mathrm{Id}$. at 3 .

${ }^{73}$ In most cases, it appears that the State Authorities were included as part of the States, but many other Authorities qualified as special districts.

7t A financial news editor recently offered an estimate of 3,000. Public Authorities, Wall Street Journal, Dec. I, xg60, p. I, col. I.

75 The breakdown: U.S. Government, I; States, 48; Counties, 3,047; Municipalities, I7,I83; Townships \& 'Towns, I7,I98; School Districts, 50,446; and Special Districts, 14,405. Also listed but not included in the total were"the then territorial governments of Alaska and Hawaii and their local government units, as well as those of Puerto" Rico. "II I957 Census, No. I, Summart of Pubitc Enipioiment 4 (I958).
} 


\section{B. Interstate}

Arkansas-Mississippi Bridge Commission

Bi-State Development District (Illinois \& Missouri)

Breaks Interstate Park Commission (Kentucky \& Virginia)

Clinton Bridge Commission (Iowa \& Illinois)

Delaware River Basin Water Commission (Delaware, New Jersey, New York \& Pennsylvania)

Delaware Port Authority (New Jersey \& Pennsylvania)

Delaware River Joint Toll Bridge Commission (New Jersey \& Pennsylvania)

Lake Champlain Bridge Commission (New York \& New Jersey)

Maine-New Hampshire Interstate Bridge Authority

Port of New York Authority (New York \& New Jersey)

Tennessee-Missouri Bridge Commission.

\section{Internotional}

Niagara Falls Bridge Commission (Canada \& New York)

Buffalo \& Fort Erie Public Bridge Authority (Canada \& New York).

Based primarily on the Bureau's information, ${ }^{77}$ the selection was generally limited to State-created Public Authorities which are authorized to issue revenue bonds and to fix and collect tolls, rentals, or other charges, and (notwithstanding the Bureau's specifications ${ }^{78}$ ) appear to be, if not completely autonomous, at least more independent of than dependent upon State control. Receipt of incidental federal or State aid by the Authority was not considered to be a disqualifying factor if issuance of bonds was authorized. It is emphasized that this is by no means a complete listing, but it was felt that the information might be of interest to illustrate some of the important State Authorities and the variety of undertakings reflected thereby. ${ }^{79}$

\section{$\mathrm{V}$}

\section{Some Legai Aspects}

As with any corporate enterprise, the scope of possible litigation affecting Authorities is extensive. But a great deal of Authority litigation arises by reason of the fundamental problem encountered in Authority dealings generally: What is the nature of the Authority? We have observed the almost chameleon-like aspect of the Authority creature which occasionally seems to change its characteristics when it is sought to be engaged in focus with respect to its immediate environment. Many legal complications arising from particular Authority transactions are resolved upon answering the fundamental question. Space limitations permit no more than passing consideration.

Legal actions frequently have been of a "friendly" nature brought about by a mutual desire of interested parties to test the legal basis of a new Authority and the validity of its revenue bond procedures. Judicial approbation and validation of its bonds, as well as recognition of the Authority's legal powers generally, are sometimes welcome prerequisites for the accomplishment of any constructive efforts by a Public Authority. Investors uncertain of subsequent judicial acquiescence in Authority operations do not provide a likely market for its bonds.

\footnotetext{
${ }^{77}$ Correlated with pertinent listings of bond issue data; JoHn MOODY, Municipal AND GovernMeNTal Mandar (rg6r).

${ }^{78}$ I I 957 Census, No. I, Governments in the United States 7.

70 No effort was made to tabulate other than State-level bodies; e.g., the impracticality of listing Pennsylvania's more than 1200 municipal Authorities needs no further explanation.
} 
Other, less friendly suits have been brought to declare legislative grants unconstitutional, and thus to thwart the use of the Authority device. ${ }^{80}$

\section{A. The Authority as a Valid Separate Entity}

The power of the legislature to establish a Public Authority to undertake any one of countless governmental responsibilities is practically unquestioned. In the absence of a constitutional limitation, there appears to be little or no restraint upon legislative power to establish any form of corporate Authority endowed with necessary faculties and attributes to accomplish a legitimate public purpose. A truly governmental function remains so whether performed directly by the sovereign or by a separate entity for the sovereign. ${ }^{81}$

A State constitutional provision that the State shall not be made a defendant in any court does not limit the power of the State to delegate governmental functions to quasi-public corporations which have no power to tax and are not dependent upon the State for financial support, even though such corporations are afforded no immunity from suit or liability. ${ }^{82}$ But the "governmental functions" may be subject to careful scrutiny to assure that Authority operations will not compete with private enterprise. ${ }^{83}$

In addition, the creation of an autonomous Authority, even with corporate form and status, for a public purpose does not come within a constitutional inhibition to the effect that "no [private] corporation shall be created by special law." ${ }^{34}$

The Public Authority frequently is challenged upon grounds alleging infringement of constitutional limitations upon the public debt by use of its borrowing powers. With some few exceptions-usually to be distinguished by consideration of unique factors-the courts generally have upheld the Authority powers as not violating public debt limitations. A number of courts have repelled frontal attacks upon the constitutionality of the revenue-bond and user-charge mechanism by defining the Authority in terms of an entity separate and distinct from the State, whose debts can in no way bind the State. ${ }^{85}$ Thus, the Supreme Court of Georgia has stated: ${ }^{80}$

${ }^{80}$ Council Report 95.

81 "There is no prohibition . . . against the creation by the legislature of every conceivable description of corporate authority, and when created to endow them with all the faculties and attributes of other pre-existing corporate authorities." People v. Salmon, 5 I Ill. 37, 50 (I869). And see, e.g., United Statcs v. Washintgon Toll Bridge Authority, rgo F. Supp. 95 (W.D. Wash. 1960); Kennebec Water Dist. v. City of Waterville, $96 \mathrm{Me}$. 234, 52 Atl. 774 (I902); and Brockenbrough v. Board of Water Comm'rs, 134 N.C. I, 46 S.E. 28 (1903).

${ }^{82}$ Hope Natural Gas Co. v: West Va. Turnpike Comm'n, I05 S.E.2d 630 (W. Va. 1959), distinguishing "a somewhat borderline decision" which had held the State Office Building Commission (having authority to construct. buildings to house. State agencies, and supported in part by State funds) to be a State agency immune. from suit: City of Charleston v. Southeastern. Constr. Co.r 134 W. Va. 666, 64 S.E.2d 676 (I950).

${ }_{88}$ See remarks in dissenting opinion" calling attention to one phase of a Port Authority's purpose as "a step toward placing the State... . in operi competition with private enterprise . . . the very lifeblood of a free democracy." Sigman v. Brunswick Port Authority, 2I4 Ga. 332, 338, I04 S.E.2d 467, 473 (I958).

: : "sec, e.g., Meisel v. Tri-State Airport Authority, 135 W. Va. 528, 540, 64.S.E.2d 32, 39 (1951).

${ }^{85}$ See, e.g., Andres v. First. Arkansas Dev. Fin. Corp., 324 S.W.2d 97 (Ark. 1959); Opinion of the 
While the authority is an instrumentality of the State, it is nevertheless not the State, nor a part of the State, nor an agency of the State... [and] its revenue bonds . . . are first, last and always a corporate debt of the Authority and in no sense a debt of the State.

This line of reasoning can be traced to an early United States Supreme Court determination, in an important jurisdictional problem, to the effect that a Stateincorporated bank, even though the State be one of the incorporators and hold an interest therein, was not to be considered as the State; and that the State, as a member of the corporation, did not exercise its sovereignty with respect to the bank's activities: ${ }^{87}$

... when a government becomes a partner in any trading company, it divests itself, so far as concerns the transactions of that company, of its sovereign character, and takes that of a private citizen. Instead of communicating to the company its privileges and its prerogatives, it descends to a level with those with whom it associates itself, and takes the character which belongs to its associates, and to the business which is to be transacted.... The state . . . by giving to the bank the capacity to sue and be sued, voluntarily strips itself of its sovereign character, so far as respects the transactions of the bank, and waives all the privileges of that character....

\section{B. The Special Funds Doctrine}

Those who contend that the issuance of bonds by an Authority necessarily binds the State as the ultimate guarantor frequently are checked by the application of the "special funds" doctrine. 88 This doctrine-largely a development of the law of municipal corporations-means, in effect, that loans which are to be liquidated by the use of particular funds derived from the revenues of the activity involved do not constitute debts within the meaning of any constitutional restriction regarding the incurrence of a State debt. ${ }^{80}$ Under this view, the Authority's obligations rest upon its own resources, as the bonds are payable solely from a specified revenue source, and pledge of the State credit is expressly disclaimed. However, an Authority

Justices, 270 Ala. I47, II6 So.2d 588 (1959), distingiushed from Opinion of the Justices, 264 Ala. 176,85 So.2d $39 \mathrm{I}$ (1956) (plan to procure funds for payment of current operating expenses by issuance of bonds payable out of proceeds of State taxes).

${ }^{80}$ McLucas v. State Bridge Bldg. Authority, 210 Ga. r, 6, 77 S.E.2d 53I, 535 (1953). (Emphasis added.) The court cited an earlier ruling concerning the University Regents, in which the court described the University "corporation" as "a mere creature of the state" and added that the "debt of the creature does not stand upon a level with the creator and never can rise thereto. It is first, last and always a debt of the creature and in no sense a debt of the creator." State v. Regents of Univ. Sys. of Georgia, 179 Ga. 210, 175 S.E. 567 (1934). See, to the same effect, Sigman v. Brunswick Port Authority, $2{ }_{4}$ Ga. 332, ro4 S.E.2d 467 (1958); Indiana State Toll-Bridge Comm'n v. Minor, 236 Ind. I93, 139 N.E.2d 445 (1957); and Opinion of the Justices, 334 Mass. 721, 136 N.E.2d 223 (1956).

${ }^{87}$ Bank of the United States v. Planter's Bank of Georgia, 22 U.S. (9 Wheat.) 904, 907-08 (1824).

${ }^{88}$ Early application of the theory is traced to the decision in Winston v. Spokane, I2 Wash. 524, $4 \mathrm{I}$ Pac. 885 (1895). See Shestack, The Public Authority, ro5 U. PA. L. Riv. 553, 557-58 (1957).

${ }^{80}$ See Gerwig, Public Authorities: Legislative Panacea?, 5 J. Pن́в. L. 388, 393 (I956); Comment, Obligations of a State-Created Authority: Do They Constitute a Debt of the State?, 53 MICH. L. REv. 439, 440 (1955), for a resume of cases; see also Nehemkis, The Public Authority: Some Legal and Practical Aspects, 47 Yale L.J. 14, $2 \mathrm{I}_{*}$ (1937). For an extensive list of prior cases applying the doctrine, see Foley, Municipal Financing of Public Works, 4 Fordinis I.: REv: 13 n.73 (I935). 
issuing bonds under a disclaimer that State credit is pledged may find its particular scheme judicially construed to result in a pledging of the sovereign credit and thus risk invalidity of its modus operandi. ${ }^{90}$

The special funds doctrine now is generally accepted and was applied recently to uphold bond issues by office building and ports Authorities, ${ }^{01}$ re-emphasizing the theory that special funds should be derived only from a source related to the project for the promotion of which the obligation is pledged..$^{92}$

A distinction has been drawn between a provision requiring the State to subsidize an Authority, and a right to contract with the Authority for its services. It was held that the State may become indebted to the Authority for goods and services but cannot become indebted to the bondholders of the Authority or the general public for defaults of the Authority. ${ }^{93}$

\section{Sovereign Immunity and Tort Liability}

A basic legal problem affecting Public Authorities concerns the application of the doctrine of sovereign immunity. The merits of the doctrine generally will not be discussed here except to note that increasing disfavor may well augur waning application of the theory to Authorities.94

Generally, in the case of wholly-owned government corporations authorized to sue and be sued, it appears that this power is sufficient to establish a waiver of immunity from suit. ${ }^{95}$ However, some States have been reluctant to depart from old established precedents and, in absence of persuasive statutory direction, are unwilling to subject Authorities to greater liability than is acknowledged for the sponsoring State.

In cases where the immunity doctrine was applied, the courts stressed the close interest and relationship of the State to the particular activity, along with the absence of a specific waiver of immunity. ${ }^{96}$ This is especially true in personal injury cases. ${ }^{97}$

${ }^{80}$ Ayer v. Commissioner of Administration, I65 N.E.2d 885 (Mass. 1960). This is especially true if the plan embodies the use of general funds to make up a deficiency, as in Turnpike Authority of Kentucky v. Wall, 336 S.W.2d 551 (Ky. 1960).

${ }^{21}$ Book v. State Office Bldg. Comm'n, 149 N.E.2d 273 (Ind. 1958); North Carolina State Ports Authority v. First-Citizens Bank \& Trust Co., 242 N.C. 4I6, 88 S.E.2d I09 (I955). Cf., for ccrtain earlier distinctions, State Ports Authority v. Arnall, 201 Ga. 713, 41 S.E.2d 246 (1947), and Williamsburg Sav. Bank v. State of New York, 243 N.Y. 23I, I53 N.E. 58 (1926); and see criticism of Morris, Evading Debt Limitations with Public Building Authorities: The Costly Subversion of State Constitutions, 68 YALE L.J. 234-268 (1958).

${ }^{22}$ See Arthur v. Johnston, I85 S.C. 324 , 194 S.E. I5I (1937).

${ }_{93}$ McLucas v. State Bridge Bldg. Authority, 210 Ga. I, 77 S.E.2d 531 (1953). For additional ramifications of the special fund doctrine, including the related limited special fund doctrine (usually involving, as to municipal corporations, the financing of additions to existing systems rather than an original system), see Charles S. Rhyne, Municipal LAW $\$$ 14-7, at 335 (1957).

os For some recent trends, see Annots., 60 A.L.R.2d II98 (1958), and 62 A.L.R.2d 1211 (1958). See also Muskopf v. Corning Hosp. Dist., 55 Cal.2d 2II, 359 P.2d 457 (196r); Lipman v. Brisbane Elementary School Dist., 55 Cal.2d 224, 359 P.2d 465 (196r).

${ }^{\circ 5}$ See Keifer \& Keifer v. Reconstruction Fin. Corp., 306 U.S. 381 (1939), and Annot., 83 L. Ed. 794,807 (1939).

${ }^{90}$ See, e.g., Fowler v. California Toll-Bridge Authority, I28 F.2d 549 (9th Cir. 1942); Kansas City Bridge Co. v. Alabama State Bridge Corp., 59 F.2d 48 (5th Cir. 1932); Masse v. Pennsylvania Turnpike Comm'n, I63 F. Supp. 510 (E.D. Pa. 1958); Chicago Stadium Corp. v. Indiana, 123 F. Supp. 783 (S.D. 
Courts in such cases also have construed specified powers of the sue-and-be-sued variety in context with powers to contract and words of similar import as relating. to procedural rights only and have not deemed the suability provision as constituting. a waiver of immunity or consent to suit for tort liability. ${ }^{98}$ And in other situations, especially in the case of highway or turnpike and hospital Authorities, the apparent. waiver has been construed strictly so as to relate only to such actions as are necessary. to carry out the purpose of the activity. ${ }^{99}$

A significant decision of the United States Supreme Court in the TennesseeMissouri Bridge case is of particular interest here. Here, an interstate Authority was. established pursuant to the compact clause of the Federal Constitution. In considering the compact as a "means of safeguarding the national interest" rather than merely" a "supple device for dealing with interests confined within a region," the Court disregarded the local law of the respective States and found, as a consequence of congressional approval of a sue-and-be-sued clause in the compact, that the bi-Stateinstrumentality was amenable to suit for tort liability.$^{100^{\circ}}$

A federal court of appeals found that a Pennsylvania Turnpike Commission, authorized by statute to sue and be sued in its own name, was neither the alter egoof the Commonwealth nor endowed with the Commonwealth's sovereign immunity from suit in a tort action based on negligence. ${ }^{101}$

Other courts also have construed the sue-and-be-sued power as an effective waiver of immunity. ${ }^{102}$ Such decisions may be ascribed to an increasing understanding of the need to protect the public from functions (though carried on ostensity for governmental purposes) which are indistinguishable from private business activities. The liberal attitude doubtless was influenced by the fact that many of the early decisions applying the immunity doctrine in the general area of government liability weremade within a context of relatively limited governmental activity, and then generally in cases affecting the exercise of traditional governmental or police powers.

Another recent view-with an eye toward the point of ultimate pecuniaryimpact-suggests that the application of the sovereign immunity doctrine cannot bejustified in the case of independent Authorities because the financial burden of liability would not, as in the case of the State, fall on general treasury funds but.

Ind. I954); Spangler v. Florida State Turnpike Authority, I06 So.2d 42I (Fla. I958); Hosterman v.. Kansas Turnpike Authority, 183 Kans. 590, 33 I P.2d 323 (1958); Rice Hope Plantation v. South Carolina. Pub. Serv. Authority, $2 \times 6$ S.C. 500, 59 S.E.2d 132 (1950).

${ }^{07}$ See Connor v. South Carolina Pub. Serv. Authority, 91 F. Supp. 262 (E.D.S.C. I950).

${ }^{08}$ See Elizabeth River Tunnel Dist. v. Beecher, 117 S.E.2d 685 (Va. I96r).

${ }^{10}$ Annots., 62 A.L.R.2d I222 (I958), 25 A.L.R.2d 203, 224 (I952).

100 Petty v. Tennessee-Missouri Bridge Comm'n, 359 U.S. 275 (1959), reversing 254 F.2d 857 (8th. Cir. 1958). Of interest here is a 1960 Governors' Conference resolution opposing "federal interference"with already established interstate compact agencies. Resolutions, 33 STATE Government 182 (1960).. ${ }^{102}$ Pennsylvania Turnpike Comm'n v. Gerr, 282 F.2d 293 (3d Cir. I960), cert. denied, 365 U.S.. $8 I_{7}(\mathrm{rg} 6 \mathrm{x})$.

${ }^{102}$ Hoffmeyer v. Ohio Turnpike Comm'n, I66 N.E.2d 543 (Ohio C.P. 1960); Linger v. Pennsylvanias Turnpike Comm'n, $15^{8}$ F. Supp. 900 (W.D. Pa. 1958); Taylor v. New Jersey Highway Authority, 22: N.J. 454, 126 A.2d 313 (1956). Tort liability has been recognized, especially in Housing Authority cases. See, e.g., Knowles v. Housing Authority of Columbus, 212 Ga. 729, 95 S.E.2d 659 (I956); Muses v.Housing Authority, 83 Cal. App. 2d 489, 189 P.2d“305 (1958); Annot., 61 A.L.R.2d I246, 1247 (1958).- 
would be chargeable against the tolls, rents, or other charges which accrue to the Authority in its own right. Critics of this theory reiterate the oft-suggested possibility that the State, though not legally liable, might feel obliged to use State funds to liquidate the Authority's debt. ${ }^{103}$ Nevertheless, in arguing for a literal interpretation of sue-and-be-sued clauses, the conclusion was expressed that historical policies behind sovereign immunity would not seem to be infringed to any significant extent by a refusal to apply the doctrine to independent Authorities. ${ }^{104}$

The trend in New York, for instance, has been drifting away from the sovereign immunity doctrine. Although the Port of New York Authority originally was held immune to suit, ${ }^{105}$ subsequent legislation waived immunity, including liability for tortious acts; and more recently, the New York legislative commission, in order "to remove doubt" as to those Authorities which were not made amenable to suit by specific provision, recommended that all New York Authorities expressly be made liable for actions in tort. ${ }^{108}$

\section{Legislative Control}

The precise degree of control that legally may be exercised over the Authority by the legislature involves an intriguing array of economic, social, philosophic, as well as legal considerations. The true nature and significance of this issue was emphasized when the Port of New York Authority officials declined to furnished certain internal records to a congressional subcommittee which undertook an inquiry into the operations of the bi-State Authority to determine the necessity for legislation affecting the original compact under which Congress approved the Authority. Despite apparently conciliatory efforts by Governors Rockefeller and Meyner, of New York and New Jersey (at whose insistence the Authority files were withheld), the important jurisdictional questions could not be resolved short of contempt proceedings against one of the nation's best known Authority administrators, Austin J. Tobin, executive director. As the controversy brings into sharp focus the scope of the congressional investigative function, it is unlikely that the matter will terminate with the adverse judgment of the federal trial court against the Port Authority official, ${ }^{107}$ but full appellate consideration well may ensue.

When a Massachusetts legislative commission in 1950 asked an Authority for information to aid in its survey of State government operations, the executive director replied: "The Authority, while recognizing the desirable and laudable purposes for which your committee is functioning, feels there is a possible error in your request ... it is the opinion of the Authority that our activities do not come within the scope

${ }^{103}$ Such assistance occasionally has been given. Council REport 78.

104 Note, Thé Applicability of Sovereign Immunity to Independent Public Authorities, 74 Harv. L. REv. 7I4 (I96r).

105 Howell"v. Port of New York Authority, 34 F: Supp. 797 (D.N.J. 1940).

${ }^{100}$ N.Y. STUDY 99.

${ }^{1}{ }^{107}$ United States v. Tobin, 195 F. Supp. 588 (D.D.C. $\times 96 \mathrm{r}$ ), decided by Judge Youngdahl, appealed to the Circuit Court. The national significance of the case was emphasized by the participation of twenty other states in a brief filed by the Attorney General for the State of Florida. See Celler, Congress, Compacts, and Interstate, Authorities, infra, at 682-702. 
of your committee." In a similar vein, a Massachusetts Authority chairman stated that his Authority was not a public corporation. Still another veteran Authority administrator described the work of certain New York Authorities with which he is associated as "business with private capital under public auspices," and criticized a bill to force New York Authorities to report more fully to the legislature as "obviously a first step towards subjecting authorities to political controls and the enervating effect of centralized bureaucratic management." The legislators, on the other hand, decried the Authorities' lack of sympathy for "democracy."108

Regardless of the ultimate outcome of the Tobin case, practicalities suggest that the degree of control should be flexible, depending substantially on the apparent requirements of a given situation. The measure of control should correspond to the degree to which the Authority accomplishes its purpose. As the mission of the Authority generally is one which a legislative body has deemed inappropriate for customary governmental operation, minimum controls normally should be exercised. However, if improper management imperils the successful completion of the objective, the duty of the sovereign power is clear, even to the ultimate point of abolition, if satisfactory solution cannot be accomplished by the lawmakers and the Public Authority.

\section{E. Taxation}

Although a Public Authority normally is not considered a political subdivision of a State, nevertheless provisions of the Internal Revenue Code authorizing exemption from federal income taxes of interest on bonds issued by a political subdivision were judicially applied to the Port of New York Authority. ${ }^{109}$ The rationale here seems to be that at least with respect to tax laws, the term "political subdivision" includes instrumentalities as well as traditional political entities such as the special districts and other territorial units.

Despite the federal government's contention that an Authority which took over an extensive ferry system previously operated as a private business thereby entered into a proprietary activity not entitled to immunity from taxation, a federal district court has also held recently that the maintenance of a highway system, including necessary bridges as well as ferry services as essential links in the system, was a clear exercise of a traditional and essential governmental function and therefore not subject to federal transportation taxes. ${ }^{110}$

As a government instrumentality, the Authority is not likely to be subjected to State property taxation. ${ }^{111}$ It is not unusual, however, for an Authority to make

${ }^{108}$ Cameron, Whose Authority?, AtLantic Monrmex, Aug. 1959, pp. 38, 39-40.

${ }^{100}$ Commissioner v. Shamberg's Estate, 144 F.2d 998 (2d Cir. I944), cert. denied, 323 U.S. 792 (1944); Commissioner v. White's Estate, I44 F.2d Iorg (2d Cir. I944); accord, as to this point, Wolkstein v. Port of New York Authority, 178 F. Supp. 209 (D.N.J. 1959): Note Judge Frank's extended dissent in Shamberg (although he conceded he "would not go to the stake" to vindicate his position), 144 F.2d at 1006.

${ }^{110}$ United States v. Washington Toll Bridge Authority, 190 F. Supp. 95 (W.D. Wash. 1960).

211 Opinion of Justices, 334 Mass. 721, 136 N.E.2d 223 (1956); and see Smith v. Smith, I2I S.E.2d II3, II 8 (Ga. Ig6I). But closer scrutiny of Authority operations for tax purposes may be expected as, 
payments in lieu of taxes to prevent undue loss of tax income by the areas involved as a result of acquisition of property by Authorities. It has been held recently that .a lessee of an Authority may be charged such "in-lieu" payments to meet demands of public policy that lessees of a public landlord should not receive a windfall at the public expense. ${ }^{112}$

\section{F. General}

The courts are not likely to overturn routine determinations by Authority administrators. On specific issues involving judicial review of administrative decisions, a federal court upheld the determination of a turnpike commission, ${ }^{113}$ while a State court even declined to review a similar case. ${ }^{114}$

Although the exercise of eminent domain by Authorities occasionally prompts challenge, courts are not prone, especially in cases involving complex problems of administration and valuation, to favor hypertechnical objections when the legislative grant is clear. ${ }^{114 a}$

When a State through a parking Authority leases public property, the proscriptions of the Fourteenth Amendment must be complied with by the lessee.114b

An effort by a labor union to remove to the federal courts an Authority's state court action to enjoin the union's picketing activities proved fruitless when it was not clear that the complaint arose under laws of the United States. 114c $^{-}$

Miscellaneous legal problems affecting the powers of Authorities generally are determined in accordance with principles of corporation law, tempered by the .always present controlling factor of the public interest.

\section{VI}

\section{An Appraisal}

\section{A. Selected Advantages and Disadvantages}

The rapid development of the Public Authority phenomenon during the years following the depression of the I930's and World War II generally was accepted at least as a practical and necessary, if not altogether ideal, governmental device. -Observers of the early trend usually cited for justification of the Authority method such primary advantages as operating efficiency because of dependence upon earnings rather than legislative largess, and the convenient credit base that affected neither

for example, in situations where Authority-type agencies acquire land which is not immediately put to use for the Authority's assigned mission. See, e.g., item involving Pennsylvania Turnpike Commission, Wall St. Journal, July 5, 196r, p. r, col. 5 .

${ }^{112}$ National Cold Storage Co. v. Port of New York Authority, 26 Misc.2d 570, 207 N.Y.S.2d 17I (Sup. Ct. I960).

${ }^{213}$ Guaranty Trust Co. v. West Virginia Turnpike Comm'n, I09 F. Supp. 286 (S.D.W.Va. I952). 114 Owens v. Oklahoma Turnpike Authority, 283 P.2d 827 (Okla. 1954), cert. denied, 350 U.S. 893 (1955).

114: E.g., Cervieri v. Port of New York Authority, 34 N.Y. I44, I67 A.2d 609, appeal (treated as a petition for certiorari) denied, 367 U.S. 487 (196I).

11kb Burton v. Wilmington Parking Authority, 364 U.S. 8ro (196r), involving refusal by lessee restaurant operator to serve a Negro.

11se South Carolina State Ports Authority v. Local 1422, International Longshoremen's Union, 191 F. Supp. 156 (E.D.S.C.), appeal dismissed, 367 U.S. 910 (196r). 
debt limits nor tax burdens. ${ }^{115}$ Further, the magnitude of tasks suited to the Authority technique involved costs which far exceeded ordinary budget possibilities for a department typical of State administration. Moreover, the concentrated effort of an Authority ordinarily could not be matched by a regular State unit burdened with diverse responsibilities. ${ }^{110}$ In addition, problems of overlapping or conflicting jurisdiction were found to be more easily resolved by the use of Authorities.

But professional commentators were not unaware of certain sensitive areas in the Authority business. For example, it was suggested that a financial default by an Authority would undoubtedly have a marked adverse effect upon the credit standing of the sponsoring governmental unit. ${ }^{117}$

And as the Authority loomed larger upon the public scene, criticisms and fears waxed louder and stronger, as for example: ${ }^{118}$

... a governmental progress achieved after years of painful civic effort has been nullified by the tendency to take "normal" functions away from the normal agencies of government and turn them over to new autonomous agencies that are quasi-public, quasi-private and, if one may be facetious, just plain quasi-quasi.

Also:119

... We are trying to evade constitutional or statutory debt limitations; we are refusing to face up to government-wide problems of poor personnel, financial and administrative practices; we are advocating basic reorganizational efforts . ... and then nullifying them with a series of weak-brained efforts .... [W] avoid politics by playing a new and perhaps dirtier kind of "non-politics." We are promoting a new type of government that may prove to be not only nonprofit and non-political but nonsensical as well .... General government is in danger of being superseded by a set of Authority-type ganglia directed by a small, weak brain.

More importantly, it seemed, citizens stood in danger of losing their right of representation in the supervision of governmental operations. Even the course of industrial development was largely subject to helmsmen beyond the traditional influences of government and the electorate.

In 1953 the Council of State Governments fairly defined the Authority dilemma: $:^{120}$ .... it offers an efficient method of administering a variety of projects and ... in some circumstances its seems to be an indispensable method of financing them. Its use enables state government to provide facilities of great benefit to many citizens .... But the Public Authority is not a panacea for all the financial troubles of the States, nor does its adoption guarantee efficient administration of a project. Creation of an excessive number of Authorities, even for self-liquidating projects . . . may have undesirable consequences. It may weaken gubernatorial and legislative control over major state functions and become a divisive element in over-all public policy. Finally the establishment of too many Public (1937).

${ }^{115}$ See, e.g., Nehemkis, The Public Authority: Some Legal and Practical Aspects, 47 YALE L.J. I4

${ }_{110}$ See Council Report iro.

117 Id. at 33 .

${ }^{128}$ McLean, Use and Abuse of Authorities, 42 NAT. MUN. Rev. 438, 44I (1953).

${ }^{110}$ Id. at 444 .

${ }^{290}$ COUNCIL RePort II3-r 4 . 
Authorities in a State . . could cause an undue share of the burden of support for State activities to be shifted from general taxes to special user charges.

The institution of Public Authorities as a sort of legislative catalyst to general expanded public services not conveniently possible through normal governmental operations now has weathered successive cycles of enthusiasm and rebuke. The popular surge of Public Authorities probably reached its peak during the r950's. Although new Authorities still are being established, the rate of increase has diminished, ${ }^{121}$ and many of the older ones have suspended or terminated operations. This is not altogether surprising for, in a sense, Authorities may be running out of new things to do, as one spokesman has suggested. ${ }^{122}$ But there is probably a more basic reason. Public Authorities concededly have advanced beyond the stage of novel public financing devices and now confront the inevitable fate of any flourishing political mechanism: they have become a prime target of public scrutiny.

In one case, Authority directors became involved in a conspiracy with a contracting firm to defraud the Authority on certain land contracts, leading to prison sentences for the principals in a large-scale swindle. Another case of unfavorable publicity arose when some nonsalaried members of another Authority were indicted for improper use of expense money. More recently, it was alleged that an agency which handles most of an Authority's insurance business spent large sums for purposes of inducement. This was denied on the ground that the money involved represented legitimate business expenses. ${ }^{123}$

These, of course, are isolated instances, but they indicate the constant necessity for self-imposed high business standards by Authority management officials.

The practice of successful Authorities to pay substantial salaries to chief administrators occasionally draws critical fire. Although the salaries seem high in some cases, the New York Legislative Commission in 1956 found them to be more appropriate to the responsibilities involved than are the generally lower levels of federal, state, and local executive salaries. ${ }^{124}$

As the once protective immunity of Authority operations fades, and the mysterious, almost magic manner in which Authorities developed into a new governmental dimension (in truth, perhaps a quasi-form of government-e.g., Netherton's "government by proclamation"125) is illumined by the light of searching inquiry, a more normal and acceptable status may emerge. Certainly Authorities are not sacrosanct but are subject to modifications suggested by experience.

The Public Authority has been adversely criticized as a socialistic undertaking. ${ }^{120}$ It might seem doubtful whether such adverse criticism remains valid today in the face of the evolution of governmental objectives. A veteran Authority spokesman says

${ }^{131}$ Wall Street Journal, Dec. I, 196o, p. x, col. I.

${ }^{122}$ Statement by Wade S. Smith, ibid.

193 Ibid.

${ }^{124}$ N.Y. Srudy 204, and Wall Street Journal, Dec. I, 1960, p. I, col. I.

${ }^{125}$ Netherton, Area Development Authorities: A New Form of Government by Proclamation, 8 VAND. L. REv. 678 (1955).

${ }_{120}^{\circ}$ See Foley, Revenue Financing of Public Enterprise, 35 MrCH. L. Rev. I (1936). 
that in any case, this charge is misdirected, for the objection relates to the task chosen by the legislature rather than to the Authority as a technique. ${ }^{127} \mathrm{~A}$ specific rebuttal for this type of general criticism can be found in the case history of the Long Island Transit Authority which was established to rehabilitate a privately-owned bankrupt railroad. When its purpose was accomplished, including the return of the railroad to private ownership, the Authority's enabling act was repealed. ${ }^{128}$

Authorities by their nature tend to assume an unnecessary accumulation of power, removed as they are from direct administrative, legislative, or electoral control. Some call this empire-building. ${ }^{129}$ Originally conceived to accomplish a specific objective, many Authorities have remained in business after completing a basic project, in order to commence new ventures. ${ }^{130}$ An Authority's policies, in fact, can predetermine the direction of economic movement within its area of influence. Consequences of such decisions may not become apparent until long after any effective counteraction can be mounted. Unrestricted, a Public Authority conceivably could develop into an extra-legal power of indefinite proportions.

To avoid the eventualities predicted by pessimistic observers, legislative bodies should ponder anew the basic condition under which many modern Authorities were born: The necessity for an expedient to overcome restrictions imposed upon other administrative tools. The possibility of minimizing constitutional debt controls should be explored because the need for rigid limitation has become something of a question mark, especially as the courts have tended to recognize known community desires despite possible constitutional barriers. ${ }^{131}$ More flexible and realistic than a constitutional limitation is the marketplace for securities-an effective barrier against spendthrift communities. ${ }^{132}$ It has been argued that debt limitations do not in fact limit but simply encumber the fiscal processes and ultimately increase the cost of public facilities, ${ }^{133}$ as, for example, by increased interest on bond borrowings not backed by the general credit of the State. Constitutional reform in this area may reduce the need for wholesale Authority operations and bring bona fide governmental operations within reasonable control. Still, some extremists assert that there is no middle ground: either the Authority or the debt restriction must go. ${ }^{134}$

It is not intended to imply that the Authority, as a whole, has not proved itself to be a workable device. ${ }^{135}$ There are too many concrete examples of dramatic accomplishments which were well-nigh impossible of achievement by other means.

127 Tobin, supra note 10, at 27 .

${ }^{128}$ N.Y. STUDY 35.

120 Wall Street Journal, Dec. I, I960, p. I, col. I.

${ }^{130}$ E.g., a Port Authority embarking on urban renewal.

${ }_{132}$ Magnusson, Lease-Financing by Municipal Corporations As a Way Around Debt Limitations, 25 Geo. Wash. L. Rev. 377, 395 (I957).

132 Ibid.

${ }^{133}$ Landers, Constitutional Provisions on Taxation and Finance, 33 State Government 39 (I960).

${ }^{134}$ Morris, Evading Debt Limitations with Public Building Authorities; The Costly Subversion of State Constitutions, 68 YALE L.J. 234 (1958).

${ }^{136}$ See, e.g., Netherton, Area-Development Authorities: A New Form of Government by Proclamation, 8 VAND. L. REv. 678, 696 (I955). 
It is suggested, however, that the Authority as a prescription for debt limitation problems is an extraordinary remedy which should not be used in the case of ordinary governmental needs.

Authority spokesmen decry the need for executive and legislative controls over Authority operations. Theoretically, their position is sound, for in the ideal environment of an efficient Authority accomplishing a substantial and useful public service, with an alert executive and legislature in the background, the exercise of actual control would be minimal. To achieve and maintain this utopian existence, the Authority is bound to implement sound management policies in every area of activity. Its top administrators must adhere to strict ethical standards to refute even the slightest suspicion of impropriety. Indeed, the Authority by its unique status can develop the high standards of public service ${ }^{136}$ that are desirable in all government areas.

\section{B. Conclusions}

The history of Public Authorities in the United States, especially at State and lower political levels, establishes their popular use as a governmental instrumentality primarily engaged in financing and operating substantial public works not feasible for normal government undertakings.

Their extremely rapid development in recent years-largely influenced by longcontained needs for expansion of public facilities-in many instances was accompanied by a lack of planned research and orderly legislation which probably would have reduced complaints, criticism, and misunderstanding over their use.

General acceptance of the Public Authority form in its usual echelons of operation (municipal, district or county, state and interstate) imposes an implied responsibility for high-grade standards of performance upon all concerned-from conception of the idea through the legislative implementation thereof and the construction, operation, maintenance, and termination of the project. Appropriate safeguards must in each phase assure a substantial discharge of the public trust implicit in the powers granted to Authorities.

Apart from generally favorable judicial recognition, areas of lingering doubt over the scope and manner of Authority operations may be resolved by comprehensive legislative task forces qualified to audit the need and application of Public Authorities in the local environment, as well as by impartial groups, including the Council of State Governments, whose perspective affords a broader approach to such problems.

Distinctive objectives and influences bearing on a particular Authority make it imperative to subject individual Authorities to the laboratory of political, economic, social, and legal research and analysis. Generalities must be subordinated to the pertinent needs of a given Authority, viewed as a part of an integrated governmental scheme. ${ }^{137}$ In short, the details of specific Authority operation must be custom-built

${ }^{136}$ Tobin, supra note 10 , at 25.

${ }^{137}$ For instance, whether exclusive ex-officio maangement of an Authority or a combination of 
in each case and can perhaps be determined only after actual experience factors are available for study.

On the other hand, some random observations of a broad nature may be apposite:

A comprehensive general Authority statute with special provision for specific Authorities provides a sound basis for systematic Authority. operation as well as for guidance in litigation where necessary.

The extent of broad government powers for Authorities, especially those which involve eminent domain, subpoena, police regulation, etc., should be delineated with care and attuned to realistic requirements.

Excessive appointment of ex-officio personnel to the governing body sometimes is difficult to justify. This is especially true in the case of officers whose official responsibilities may encompass legal or judicial consideration of Authority activities. A balance of ex-officio and other directors offers a fair compromise between government and business representatives.

The Public Authority appears to be especially effective when jurisdictional barriers would tend to bar necessary development or expansion of facilities beyond the scope of a particular political subdivision. At least at the lower levels of the governmental hierarchy, particular care should be given to the adequacy of controls (without, however, destroying the essential independence of Authority operation) to permit proper evaluation by the sponsor. Conversely, if the primary purpose of the Authority is to overcome constitutional debt limitations, the practical possibility of modifying such restrictions should be carefully explored with a view toward pursuing the desired objective within the framework of existing government machinery.

The determination of the proper degree and nature of control to be exercised by the sponsoring body involves a delicate adjustment to specific needs. Over-control tends to defeat the purpose and characteristic operation of the Authority device. At the other extreme, wholly independent operations of the Authority in a completely autonomous vacuum may undermine its own effectiveness, either by leading to excessive exercise of power or by breeding suspicion of improper practices. Quite apart from the issue of control per se, there is a need to establish appropriate procedures for reporting statistics and data for general census purposes and for technical and legal research and study.

In I953, the Council of State Governments found:138

The Public Authority has become a major instrument of government, and it is a growing one. Its success in the future will depend on sound decisions as to the circumstances under which it should be used and on the character of its administration in action.

The 1953 conclusion is still valid. Just as a highly developed mechanical device can increase the efficiency of a skilled craftsman, the Authority provides a means

government officers and private citizens is better cannot be determined for all Authorities within a political subdivision. Similarly, the alternatives of using salaried or nonsalaried directors and executives must be explored within the context of a specific problem.

${ }^{238}$ Councll Report Ir4. 
for efficiency in governmental activities, provided it is employed with discretion to meet special problems beyond the framework of normal governmental machinery and is operated by experienced administrators along competent businesslike lines. Under such circumstances, the Authority can continue to produce creditable contributions to the public service. 